\title{
Research on College Physical Education Resources Based on computer
}

\author{
network
}

\author{
Weibo Zhou \\ jiangxi police college, Nanchang, 330103, Jiangxi
}

\section{Key words: physical education teaching resources}

Abstract: the computer network with many kinds of functions is a kind of modern network appliance. Nowadays, it has also become a high tech teaching tool. The use of computer network in physical education not only improves the dull and boring teaching environment of traditional classroom, but also increases the interest of students, which leads to their active learning attitude. The change of Physical Education under the background of network has laid a solid foundation for the development of physical education.

The computer network teaching has greatly facilitated the physical education teachers, and has made no small contribution to the interest of the students. The traditional sports teaching mode to achieve a breakthrough in all aspects to enhance the comprehensive development of students to provide high-quality material basis. In the context of computer network, the realization of cooperation between human and computer. By the network resources sharing in real time, the classroom group collaborative learning and other learning models, to create a pleasant atmosphere for the learning environment of students. To enhance the initiative of the students to learn to play a role in helping students consciously participate in the classroom, in order to cultivate their innovative ability and practical ability to provide the environment.

1. The concept of computer network information resources

With the rapid development of computer technology, it is convenient for people's life. At the same time, the information of computer network is called as a magic scientific concept in life. [1]. Information is a kind of special resource is not equal to the natural or material, it is generally used as a carrier to the computer network and the diffusion media, structure and retention method to nonlinear storage, digital assembly, through a variety of information resources can be used in the computer network.

The human being through the network to obtain their own advantageous resources. The network information resources is the real existence in our life is material, we can use a variety of resources, it does make people's life more convenient, also symbolizes the human society has entered the information age.

2.Effective use of network resources for students to experience the charm of sports platform

Today, the human life is inseparable from the computer, in the economy, finance, health care, education and other fields have a very important role. On this basis, physical educators should actively encourage students in leisure time, the sports knowledge collection using the computer network, the receiving of sports publicity from the network, from the same level understanding of sports and cultural knowledge, the sports knowledge expansion has been further improved, but also the information learned in a sense by sports charm, which leads to a student's interest in physical education learning and active exploration spirit. 
3.The application of computer network in teaching provides the environment for the development of Physical Education

The computer network is a kind of modern network appliance, which is a kind of modern teaching tool. The use of this teaching tool in teaching, but also to the students to bring a fresh experience, to a large extent, to promote students' desire for knowledge.

In the teaching of physical education curriculum, there are many items in the teaching content. But the content of the exercise is usually dull as ditch water fun, very low, resulting in the students of sports lose interest in learning, learning efficiency is low, control on the basis of sports action difficult to achieve accurate level. Teachers can according to this situation, notification of new course content to teach students before class, let the students to preview, and search the corresponding action video on the Internet, there is a general understanding of sports knowledge; teachers should be in the class, the integration of the cyber source, accurate and complete information into the multimedia courseware in the teaching process, in order to better use of computer assisted teaching of [2]. This will not only enable students to improve their interest in learning, but also to enhance the ability of students to master knowledge.

4 The advantage of using computer network to acquire physical education resources

The development of physical education in Colleges and universities in our country has been developing in the field of education. If we still use the original teaching methods in teaching, there will be many problems and deficiencies in teaching. The thought of physical education workers should keep pace with the times, and the teachers should develop with the students in the course of teaching, and create a lively classroom. Physical education in Colleges and universities is mainly based on classroom teaching, which is almost blank in the development of sports activities and sports training. Moreover, the expansion of college enrollment in recent years has led to a sharp increase in the number of physical education classes in Colleges and universities. For the consideration of these problems, the physical education in Colleges and universities should bring forth new ideas to the development of information and network. It is very important to use the computer network to collect the information of physical education teaching.

Teachers should make full use of computer cyber source, in the transformation of the original teaching mode, let the students subjectivity to the maximum, to enable students to get promoted, full of vitality in the happy atmosphere in the classroom and at the same time, students studying interest also increased, innovation consciousness training. The rapid development of computer technology has become a guarantee for the motivation of physical education in our country, and also put forward higher requirements for teachers in this situation. In the process of physical education teachers should be more skilled in the use of computer networks, so that the computer network resources are fully utilized, so as to provide better services for physical education [3].

The sports workers should be good at manufacturing the sports classroom atmosphere, using the method, according to the different teaching contents, classroom teaching is abundant an antidote against the disease by using computer network technology resources, increase the student to the sports fun and learning initiative, teachers should also learn a variety of teaching methods to strengthen the knowledge, to find the most fit the teaching methods of students in self constantly practice. The use of multimedia technology to assist teaching, can attract the attention of students, causing students to further elaboration of knowledge. In the process of physical education, the application of computer network resources, greatly improve the quality of physical education 
teaching, so that physical education classroom is full of light, happy atmosphere. The use of computer information resources for teaching content becomes immutable and frozen to enable students to learn the process full of sound and colour, full of interest in sports. In view of this, the college sports workers should use computer information resources to make the class more attractive to students, causing students thirst for knowledge of sports, teachers can organize the students to the classroom demonstration sports action, let other students to participate in the discussion of the implementation of the subjectivity of the students in the classroom.

The use of computer cyber source teaching, to meet the curiosity of students, create lively classroom environment, encourage students to put more attention on the classroom, causing students to learn the fun of sports and enthusiasm, further let students send out their initiative in the process of learning knowledge in sports. Teachers should be combined with a variety of cyber source, vivid and interesting teaching content will be passed to the students, through the combination of a variety of computer media courseware, the sports course clear show students. Let the students in the course of the simple and specific understanding of physical education, to deepen the students' knowledge of the physical education, the interest of students,

\section{5 epilogue}

There is no doubt that the introduction of computer technology has brought about a new development of physical education in china. The combination of computer multimedia technology and traditional teaching, provides a new teaching environment for students in new era, but also further raises the students' need for sports knowledge, from passive learning to active learning is now the original. We have reason to believe that the integration of computer technology and physical education is the new direction of the development of physical education in the future.

1 , sports network teaching than traditional sports teaching has incomparable advantages.

Under the environment of network assisted teaching, physical education plays an important role in students' learning ability, lifelong sports consciousness and sports knowledge. It can make up for the defects of the traditional teaching content is single, the class hour is too little, and pay more attention to the students to make use of the network resources to carry on the independent study.

2 , the use of network education technology has a huge space for development.

The use of online education technology has huge development space for management and guidance of the school extracurricular sports teaching through network asynchronous teaching function, help students autonomous learning of physical education, but also conducive to the extension of school physical education, strengthen students' sports knowledge structure transform learning method, to explore new school sports teaching mode and teaching the deepening of the reform, is of great significance and development space.

3 , to avoid the limitations of the application of network education technology in physical education teaching.

The basic goal of school physical education based on the network teaching of PE, expand the role of traditional teaching can play a complementary and in some ways, can optimize the sports teaching effect obviously, but cannot exist as a single teaching form.

4, to strengthen the sports website and network materials development

The quantity and quality of sports websites and web materials are the most important problems in the development and application of network education technology in Colleges and universities. In other words, exploring the scientific teaching organization is the key to improve the quality of teaching 
and the development of sports network teaching.

\section{Reference:}

[1] Xu Miao. The integration of computer technology and College Physical Education [J]. electronic testing, 2013,18:161-162.

[2] Jin Jie. Application of computer technology in College Physical Education [J]. automation and instrumentation, 2015,10:147-148+151.

[3] Xiong Xiaoyu. Analysis on the integration of information technology and curriculum in College Physical Education [J/OL]. contemporary sports science and technology, 2015 (32)

[4] Zhao Nong. Multimedia technology in sports teaching in colleges application [J]. Journal of Shandong Normal University, 2000, (12)

Guo Hong He Zhongtao, [5]. Network information resources and teaching reform of college sports [J]. sports journal, 2000, (6).

[6] Zhu Baining et al. College sports in China to study the development of network [J]. Zhejiang sports science, 2001, (1).

[7] in red. Sports information resources under the network environment in the development of [J]. sports journal, 2001, (3)

[8] Jiang Jian, Zhang Weiming. Research and exploration of middle school physical education resources under the environment of computer network [J]. 2010,12:85-86. 